extended time-series become available over broad regions through ITASE and deep drilling projects. The Antarctic-wide comparison of glaciochemical records provides a unique opportunity to achieve an understanding of the fundamental factors that ultimately control the chemistry of a snow or ice sample. The ability to determine individual sources and pathways of aerosols, as well as mechanisms that rule precipitation efficiency and postdepositional effects, will allow the exceptionally detailed and accurate interpretation of glaciochemical records necessary for reconstructing past climate conditions with nearinstrumental quality.

\section{Note:}

This article was abstracted from Mayewski et al., in press. This paper summarizes ITASE accomplishments with references. For details concerning national programs, the ITASE Science and Implementation Plan (Mayewski and Goodwin, 1997), and other ITASE information refer to the SCAR Project Office maintained at the Climate Change Institute, University of Maine (www.ume. maine.edu/itase/).

\section{REFERENCES}

Bertler, N., Mayewski, P.A., Aristarain, A. and 46 others, in press: Snow chemistry across Antarctica, Annals of Glaciology.
Mayewski, P.A. and Goodwin, I. 1997: ITASE Science and Implementation Plan, Joint PAGES/GLOCANT Report. PAGES IPO, Bern - Switzerland

Mayewski, P.A., Frezzotti, M., Bertler, N., van Ommen, T., Hamilton, G.H., Jacka, J., Welch, B., Frey, M., Dahe, Q., Ren, J., Simoes, J., Fily, M., Oerter, H. Nishio, F., lasaksson, E., Mulvaney, R., Holmund, P., Lipenkov, V. and Goodwin, I., in press: The International Trans-Antarctic Scientific Expedition (ITASE) - An Overview, Annals of Glaciology.

\title{
A new 3000 m deep ice core drilled at Dome Fuji, Antarctica
}

YoshiYuki FUJII

National Institute of Polar Research, Tokyo, Japan; fujii@nipr.ac.jp

\section{Introduction}

On 23 January 2006, the Japanese Antarctic Research Expedition (JARE) succeeded in drilling a 3029 $m$ deep ice core at Dome Fuji in East Antarctica $\left(77^{\circ} 19^{\prime} 01^{\prime \prime} \mathrm{S}, 39^{\circ} 42^{\prime} 12^{\prime \prime} \mathrm{E}\right.$, $3810 \mathrm{~m}$ asl; Fig. 1). Dome Fuji is the third place where a more than 3000 $\mathrm{m}$ deep ice core was collected in Antarctica, after Vostok (3623 m in depth, January 1998) and Dome C (3270 $\mathrm{m}$ in depth, December 2004). The drilling will be continued next season in order to hit bedrock, which is estimated to be located $3030 \pm 15 \mathrm{~m}$ below the surface.

A previous deep ice core, of 2503 m length, was drilled at Dome Fuji in December 1996, tracing back to past $340 \mathrm{ka}$. The high resolution stable isotope record $\left(\delta^{18} \mathrm{O}\right)$ showed an extraordinary coherence (Watanabe et al., 2003) with the deep ice core from Vostok (Petit et al., 1999), which also reaches as far back in time but is located $1500 \mathrm{~km}$ away from Dome Fuji. This fact strongly supports a homogeneous climate development over the last 340,000 years on the high plateau of East Antarctica.

\section{Drilling of the new ice core}

During the 1996 drilling, the drill got stuck in the borehole and was not able to be recovered. A new drilling site was constructed in the

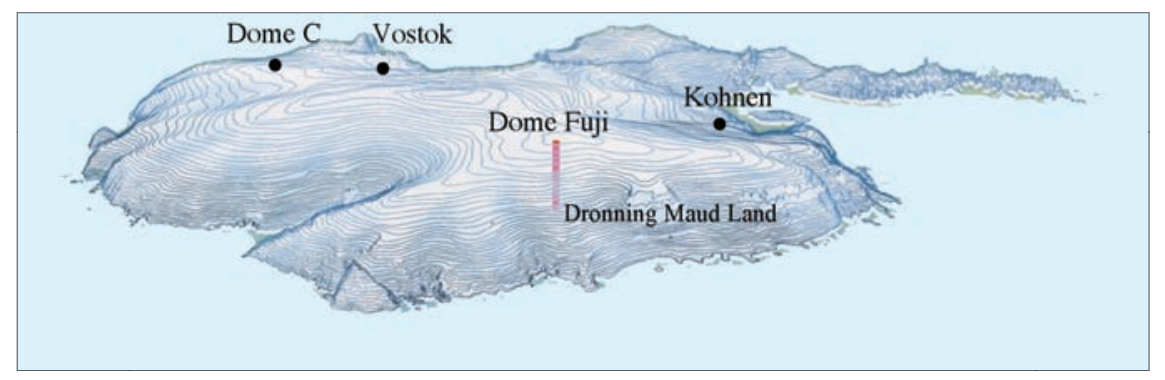

Fig. 1: A bird's eye view of the Antarctic ice sheet. Dome Fuji is located at the summit of Dronning Maud Land. This is the ideal place for ice core climate research because no horizontal ice flow movements occur.

2001/2002 season, and in December 2003, drilling was resumed 40 $\mathrm{m}$ away from the first borehole. This time, we utilized a newly developed, highly efficient drill, using a pipe with small holes $2 \mathrm{~mm}$ in diameter at intervals of $7 \mathrm{~mm}$ to act as a chip chamber to store icecutting chips. We also developed a bulb which prevents ice-cutting

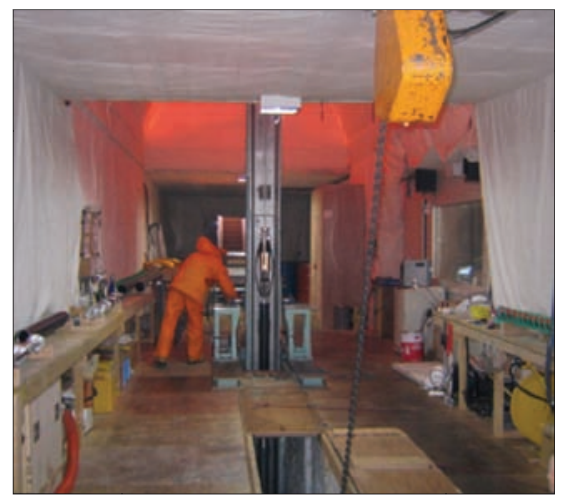

Fig. 2: Deep ice core drilling at Dome Fuji using a newly developed drill with highly efficient performance. chips from flowing out into the borehole when the drill is being winched up. The average drilling depth was $3.7 \mathrm{~m} / \mathrm{run}$ and the speed was $178 \mathrm{~m} /$ week until it got down to $3000 \mathrm{~m}$ depth. This is the fastest performance ever in deep ice core drilling in the Antarctica and Greenland. Figure 2 shows a scene of the deep ice core drilling at Dome Fuji.

Around $3000 \mathrm{~m}$ depth, the drilling speed decreased sharply as the drill hit "warm ice". We took measures against this warm ice, referring to the reports of deep ice coring at Dome C, NGRIP and others. We changed the shape of the drill cutter and the shape of the mount so that they would not easily get frozen and also coated the cutter with Teflon. However, freezing of "water" still made drilling difficult and we could drill only about $0.5 \mathrm{~m}$ each run. 


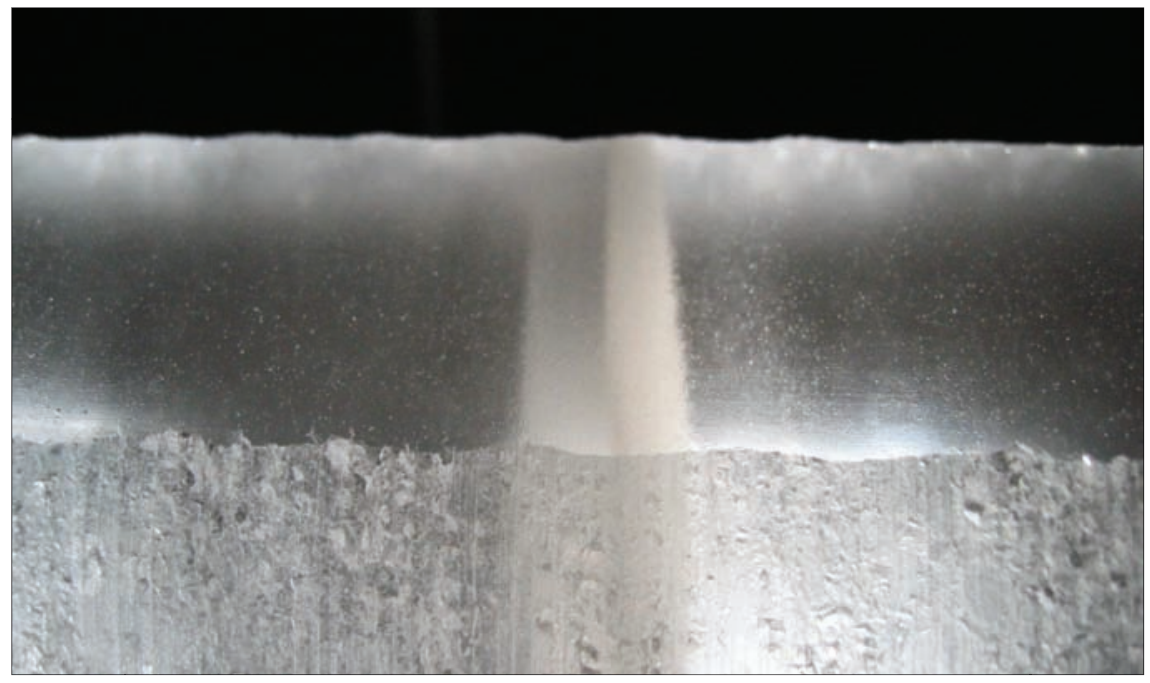

Fig. 2: A tephra layer in a half-cut ice core sample. There are a few tephra layers that were not found in the previous $2503 \mathrm{~m}$ deep ice core from Dome Fuji.

\section{Properties of the ice core}

In situ ECM (Electric Conductivity Measurement) and optical stratigraphic observations will be performed at Dome Fuji. The detailed analysis will be conducted in Japan, and we expect to determine the approximate age of the core by detecting glacial cycles and signals of the Brunhes-Matuyama magnetic reversal at around 780 $k a$, and by using a glaciological flow-model. It is difficult to say at present but we expect that the core may be $800 \mathrm{ka}$ old, as is the case for the Dome $\mathrm{C}$ deep ice core, or even older. This expected age is suggested from the fact that the geothermal heat flux in Dronning Maud Land where Dome Fuji is located is probably smaller than that of the eastern part of East Antarctica where Vostok and Dome C are located. We discovered new tephra layers (Fig. 3) that were not observed in the first $2503 \mathrm{~m}$ deep ice core.

\section{Outlook}

One half of the ice core will be kept in a storage trench at Dome Fuji and the other half will be brought back to Japan by our Antarctic research vessel in April. These ice cores will be used for various

\section{Project facts}

Project: Dome Fuji Ice Core

Contact: Yoshiyuki Fujii, fujii@nipr.ac.jp

Participants: Numerous scientists from the National Polar Institute, Tokyo, and several Japanese Universities.

Funding: Japanese National Funding

Where: Eastern Dronning Maud Land,

East Antarctica

When: 2004 ongoing

What: Deep ice cores to bedrock; Multiparameter analysis analyses at the National Institute of Polar Research, Hokkaido University, and other institutions in Japan. Our main research objectives are

1) To reconstruct the global climate and environmental changes that occurred during the past 800 ka to 1 million years.

2) To determine the impacts of the geomagnetic field reversal on the global climate and the environment around $780 \mathrm{ka}$ BP.

3) To clarify the relationship between the paleo-solar activity and the global climate.

4) To clarify the relationship between biological evolution of the ice core microbes and environmental changes.

Furthermore, if we can obtain samples of the bedrock, it may be possible to get information on the formative period of the Antarctic ice sheet in the Tertiary.

\section{REFERENCES}

Watanabe, 0., Jouzel, J., Johnsen, S., Parrenin, F., Shoji, H., and Yoshida, N., 2003: Homogeneous climate variability across East Antarctica over the past three glacial cycles, Nature, 422: 509-512.

Petit, J. R., Jouzel, J., Raynaud, D., Barkov, N.I., Barnola, J.-M., Basile, I., Bender, M., Chappellaz, J., Davis, M., Delaygue, G., Masson-Delmotte, V., Kotlyakov, V.M., Legrand, M., Lipenkov, V.Y., Lorius, C., Pepin, L., Ritz, C., Saltzman, E., and Stievenard M., 1999: Climate and atmospheric history of the past 420,000 years from the Vostok ice core, Antarctica, Nature, 399: 429-436.

\section{Vostok Ice Core project}

Vladimir Lipenkov ${ }^{1}$ on behalf of the Vostok Project Members

${ }^{1}$ Arctic and Antarctic Research Institute (AARI), St. Petersburg, Russia; lipenkov@aari.nw.ru

\section{Introduction}

Over the last 25 years, the three deep ice cores 3G, 4G and 5G, drilled at the Russian Vostok Station (Fig.1), have provided a wealth of information about past climate and environmental changes. At this site in East Antarctica, the ice thickness is $3750 \mathrm{~m}$ and the snow accumulation rate is only $2.1 \mathrm{~cm}$ of water equivalent per year. This provides the unique opportunity to obtain a long climatic record with relatively high time-resolution. In January 1998, the collaborative project between Russia, France and the United States to drill the $5 \mathrm{G}$ hole at Vostok yielded the Iongest ice core ever recovered, reaching a depth of $3623 \mathrm{~m}$. The drilling stopped $130 \mathrm{~m}$ above Lake Vostok, a deep subglacial water body that extends over a large area below the ice sheet. The $5 \mathrm{G}$ ice core can be separated into three distinct sections. The upper $3310 \mathrm{~m}$ of the core are characterized by an undisturbed sequence of ice layers. The analysis of this section of the core resulted in the first record of Antarctic ice extending through four climate cycles back to $420 \mathrm{kyr}$ BP (Petit et al., 1999). Between 3310 and $3539 \mathrm{~m}$, there are indications of ice-flow anomalies that could have altered the original stratig- 